Article

\title{
Services Evolution of Two Groundwater Dependent Wetland Ecosystems in the "Mancha Húmeda" Biosphere Reserve (Spain)
}

\author{
África de la Hera $^{1, *}$ and Fermín Villarroya ${ }^{2}$ \\ 1 IGME-Instituto Geológico y Minero de España, Geological Survey of Spain, Ríos Rosas 23, \\ Madrid 28003, Spain \\ 2 Department of Geodynamics, Faculty of Geological Sciences, Complutense University, José \\ Antonio Novais 2, Madrid 28040, Spain; E-Mail: ferminv@geo.ucm.es \\ * Author to whom correspondence should be addressed; E-Mail: a.delahera@igme.es; \\ Tel.: +34-91-349-59-67.
}

Received: 26 April 2013; in revised form: 4 June 2013 / Accepted: 13 June 2013 /

Published: 21 June 2013

\begin{abstract}
A wetland that does not comply with the ecological standards of EU Directive 2000/60/EC cannot properly provide its services. This paper presents a review of the criteria for wetland assessment based on the Spanish experience in two specific Ramsar areas: the Tablas de Daimiel and the Ruidera Lakes. The aim of this article is to consider and promote a holistic awareness of the hydrological cycle and of the wetland area ecosystems within it. The methodology developed under the umbrella of the UNESCO project IGCP 604 is applied to describe the groundwater-wetland-human interrelationship. This methodology was chosen for two reasons: (a) it is designed to assess the services the wetlands provide; (b) it focuses on groundwater dependent wetlands such as the two cases presented here. In each case, although to a different extent, agricultural activities and water management have led to important changes in the services provided by the two ecosystems.
\end{abstract}

Keywords: groundwater dependent wetland; Ramsar; Ruidera Lakes; Spain; Tablas de Daimiel; wetland ecosystem services 


\section{Introduction}

The concept of services evaluation or assessment is of particular interest in Earth Sciences and specifically within the context of dynamic wetlands, as it implies assigning a value to the benefits wetlands provide to humans. These beneficial services are linked to the human management of water, soil and the environment, and to the effects of climate change.

The evaluation of wetland services is implicit in the Water Framework Directive (WFD) under what are considered as 'water services', but is not included in the Habitats Directive (HD). Nevertheless, the protocols to determine 'ecological status' in the WFD and 'conservation status' in the HD refer to the same concept: the ecosystem quality reflected in its structure and function (Figure 1).

Figure 1. Ecological status of lake-type water body in the WFD versus ecosystem conservation status in the HD (adapted from [1]). The physico-chemical and hydromorphological features defined by the WFD correspond to the abiotic features in the HD (shown in blue); while the biological features defined by the WFD correspond to the biotic elements in the HD (shown in green).

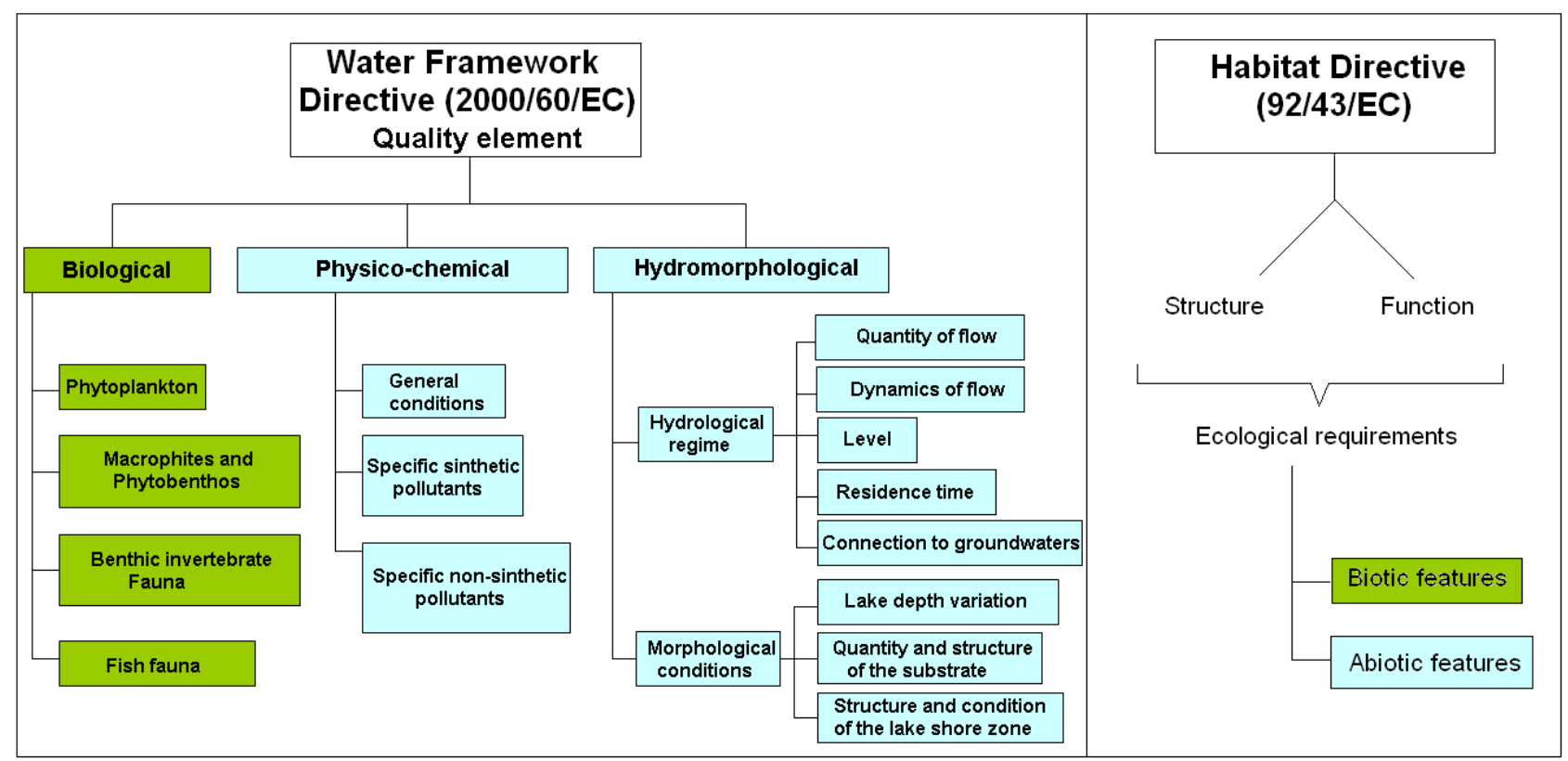

The assessment of ecosystem services has been widely discussed since the late 1980s, particularly in terms of their economic value, differentiating between the concepts of use value (i.e., to what extent they can be used to satisfy a need or improve well-being) and exchange or trading value (i.e., how much they are worth in financial terms).

Proposals do exist that aim to calculate a monetary value even though there is still no scientific consensus on their viability and how they can be applied [2]. Even so, the Total Economic Value (TEV) approach is being promoted by different projects including: EURECA, European Ecosystem Assessment; UK ecosystems evaluation and the G8 Potsdam initiative through The Economics of Ecosystems and Biodiversity Project. All these adopt the philosophy that ecosystem services will be conserved when the return on investment in monetary terms of conservation is high compared to the loss of these services [3-6]. 
The economic valuation of ecosystem services forms a very special part of the assessment process, which is often limited simply to an attempt to assign a monetary value to them, with the aim of considering the trade-offs between non-market services [7]. The monetary valuation process understood in this way is the so-called TEV approach [8,9]. This is based on the supposition that the value of ecosystems services is not included in decision-making using cost-benefit analysis, considering the services as external features of the economic system [1]. The TEV approach uses the concept of use value. In agreement with Montes and Lomas [6], this reality-based view simplifies the relationships between ecosystems and human well-being to such extremes that it completely removes them from their economic context and only captures their exchange value.

Ecosystem evaluation is approached globally in the Millennium Ecosystem Assessment [10]. Essentially, this document attempts to assess the interactions between ecosystems and humans. This is the philosophy followed in this paper using the methodology developed for the IGCP 604 project (Hydrological components of the groundwater-wetlands interactions: international cooperation for developing a new conceptual framework in Ibero-American wetlands), which seeks to draw up an integrated conceptual framework for groundwater-wetlands-human interactions through the understanding of the hydrological dynamics of the wetland-aquifer interphase. The ecosystem services assessment was created to determine the status and trends in the contributions that ecosystems make to human well-being.

The Ramsar Convention on wetlands is an agreement treaty adopted on 2 February 1971 in the Iranian city of Ramsar. Its scope of implementation covers all aspects of wetland concervation and wise use. The aim of this paper is to assess the services provided by two Ramsar groundwater dependent wetlands in the Mancha Húmeda Biosphere Reserve: the Tablas de Daimiel and the Ruidera Lakes. To do this, particular attention will be paid to service types and their assessment as proposed by Bocanegra et al. [11], adapted and modified according to the two case studies analysed. The socioeconomic and environmental contexts of these two wetland areas, approximately $75 \mathrm{~km}$ from each other, are very different. The following sections present the methodology applied, describe the historical and recent background for both these Ramsar sites, assess the past and present services provided by these wetland ecosystems, and end with a discussion and conclusions.

\section{Methodology}

The methodology proposed by Bocanegra et al. [11] is based on the identification and valuation of the services groundwater dependent wetlands provide to humans [12]. This qualitative assessment uses a scale reflecting a series of status-related factors. The physical support for this assessment is provided by worksheets designed by the IGCP 604 project team with fields used to collect basic information on each wetland [13]. The tables presented here were drawn up from data extracted from the last three sections of these worksheets covering the hydrological function status, the wetland services offered, and the factors driving direct changes to these services.

Bocanegra et al. [11] start with the concept of a wetland service. It is defined as a naturally occurring ecosystem function or process that must be used in some way by humans, since if it is not used it cannot be considered a service. These services are classified in three types (Table 1): supply, regulation and culture. Five levels of service status are then defined (Table 2) to assess trends $(\mathrm{T})$. 
A service improves when either the capacity to generate it in the wetland increases, or when the population benefiting from it increases. If either of these two criteria decreases, the service status declines. Table 3 summarizes the factors leading to direct changes in the wetland services. The assessment of these change factors is carried out using the states and trends in Table 2, except for the climate and global change group (last column on the right in Table 3) which uses the scale shown in Table 4.

Table 1. Service types provided by wetlands (adapted from [10] and [11]).

\begin{tabular}{cl}
\hline Service type & Service \\
\hline \multirow{3}{*}{ Supply } & High quality water supply \\
& Water supply for other uses \\
& Natural production of food resources \\
& Production of biological raw materials \\
\hline \multirow{2}{*}{ Regulation } & Water regulation \\
& Local climate regulation \\
\hline \multirow{3}{*}{ Culture } & Tourism \\
& Education \\
& Landscape and natural beauty \\
& Cultural identity \\
\hline
\end{tabular}

Table 2. Status descriptors of evolution trends in groundwater dependent wetland services (adapted from [11]).

\begin{tabular}{ccc}
\hline Status (S) & Trend (T) & Knowledge level (K) \\
\hline High (H) & 1-Improved & Acceptable (A) \\
Medium (M) & 2-Improving & Low (L) \\
Low (L) & 3-Stable & Nil (N) \\
Non-existent (Ne) & 4-Deteriorating & \\
Unknown (U) & 5-Deteriorated & \\
\hline
\end{tabular}

Table 3. Evaluation of factors driving changes in groundwater dependent wetlands (adapted from [11]).

\begin{tabular}{lll}
\hline & Group & Factor \\
\hline & & From influents \\
& Water extraction & Nearby groundwater \\
Intensive & & Basin groundwater \\
\cline { 2 - 3 } exploitation of & & Crops \\
resources & Biological exploitation & Fisheries \\
& & Other \\
\cline { 2 - 3 } & Mineral exploitation & Soils \\
\hline
\end{tabular}


Table 3. Cont.

\begin{tabular}{ll}
\hline \multicolumn{1}{c}{ Group } & Factor \\
\hline & Deforestation \\
& Reforestation \\
Changes in ground use & Species substitution \\
& Extensive agriculture \\
& Extensive livestock farming \\
& Building \\
& Communication routes \\
\hline \multirow{3}{*}{ Changes in hydrological cycle } & Drainage \\
& Artificial recharge \\
\hline \multirow{2}{*}{ Contamination } & Urban water contributions \\
\hline & Widespread/agricultural \\
Change-related effects & Localized urban/industrial \\
& Water quality-mineral \\
& Water quality-biological \\
\hline \multirow{2}{*}{ Climate and global change } & Oxidation resulting from lower water table \\
\hline
\end{tabular}

Table 4. Descriptor values for factors driving climate and global change in wetland services (adapted from [11]).

\begin{tabular}{cc|cc}
\hline I & Impact & F & Forecast \\
\hline $\mathrm{H}$ & High & + & Increase \\
$\mathrm{M}$ & Medium & $=$ & No change \\
$\mathrm{L}$ & Low & - & Decrease \\
$\mathrm{Ne}$ & Non-existent & & \\
$\mathrm{U}$ & Unknown & & \\
\hline
\end{tabular}

\section{Case Histories in Spain: Tablas de Daimiel and Ruidera Lakes}

\subsection{The Tablas de Daimiel}

The Mancha Húmeda includes 113 wetlands distributed in different zones [14] characterized by significant groundwater interaction. The flooded surface area covers approximately $250 \mathrm{~km}^{2}$ although it is now estimated that only $20 \%$ of the original area remains, with few of the wetlands functioning naturally [15]. It was designated by the UNESCO in 1980 as the 'Mancha Húmeda' Biosphere Reserve. The Mancha Húmeda includes seven groundwater bodies (GWBs) (Figure 2) and water body 040.007 (Mancha Occidental I), is the main collector of the system, i.e., of both the subterranean flow from the groundwater bodies to the north (Sierra de Altomira, Obispalía, Lillo-Quintanar, Consuegra-Villacañas and Rus-Valdelobos) and to the south (Campo de Montiel) (Table 5). The two most important wetlands in this complex are the Tablas de Daimiel and the Ruidera Lakes. 
Figure 2. Groundwater bodies (GWB) and wetlands studied in the Upper Guadiana Basin.
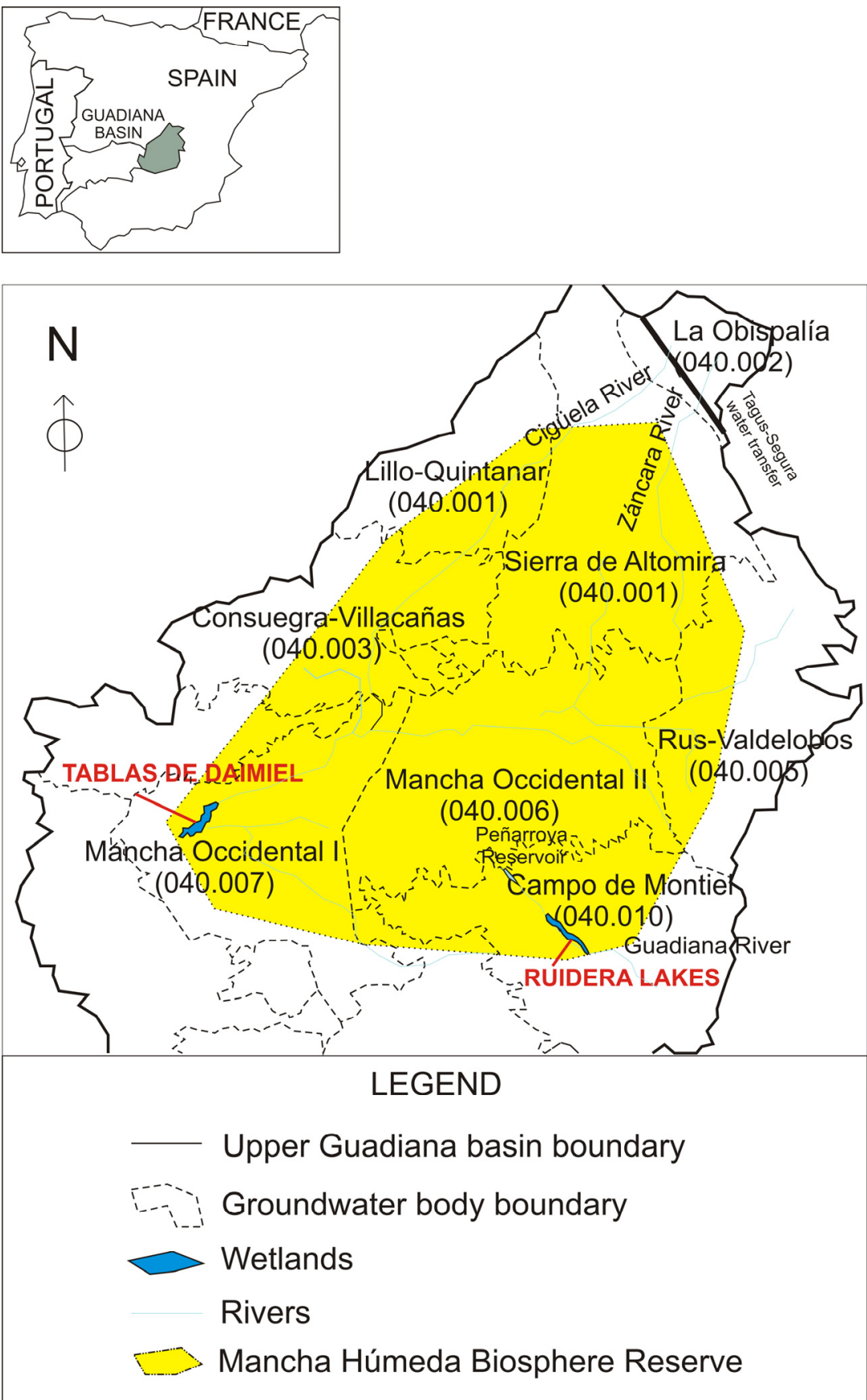

Table 5. Correspondence between aquifers and groundwater bodies in the Guadiana Basin.

\begin{tabular}{ccc}
\hline Aquifer & GWB Code & GWB Name \\
\hline Sierra de Altomira & 041.001 & Sierra de Altomira \\
\hline La Obispalía & 041.002 & La Obispalía \\
\hline Lillo-Quintanar & 041.003 & Lillo-Quintanar \\
\hline Consuegra-Villacañas & 041.004 & Consuegra-Villacañas \\
\hline & 041.005 & Rus-Valdelobos \\
Western Mancha Aquifer (WMA) & 041.006 & Mancha Occidental II \\
& 041.007 & Mancha Occidental I \\
\hline Campo de Montiel & 041.010 & Campo de Montiel \\
\hline
\end{tabular}


The Tablas de Daimiel (TD) form an area with numerous wetlands of endorheic origin and non-permanently flooded areas originating in the overflow of the Guadiana, Gigüela, Záncara and Riansares rivers (Figure 2). Under natural conditions the wetland receives brackish water from the river Gigüela, fresher water from the Guadiana, and also medium salinity from the aquifer WMA (Mancha Occidental I, Figure 2) due to effluents conditions. In dry years the TD receive water transferred from the Tajo-Segura aqueduct channelled through the river Gigüela (Figure 2), and pumped water from the underlying aquifer, as a maintenance strategy measure [16] (Table 6).

Table 6. Volumes transferred from the Tagus-Segura aqueduct to the Tablas de Daimiel (TD) through the course of the Gigüela River (data provided from [17].

\begin{tabular}{cccc}
\hline $\begin{array}{c}\text { Hydrological } \\
\text { Year }\end{array}$ & $\begin{array}{c}\text { Water diverted to TD } \\
\left(\mathbf{m i l l i o n} \text { of } \mathbf{~ m}^{\mathbf{3}}\right)\end{array}$ & $\begin{array}{c}\text { Hydrological } \\
\text { Year }\end{array}$ & $\begin{array}{c}\text { Water diverted to TD } \\
\left(\text { million of } \mathbf{~ m}^{\mathbf{3}} \text { ) }\right.\end{array}$ \\
\hline $1988-1989$ & 12.10 & $2001-2002$ & 20.00 \\
$1989-1990$ & 13.30 & $2002-2003$ & 25.00 \\
$1990-1991$ & 15.80 & $2003-2004$ & 9.40 \\
$1991-1992$ & 17.80 & $2004-2005$ & 0.00 \\
$1992-1993$ & 6.50 & $2005-2006$ & 0.00 \\
$1993-1994$ & 0.00 & $2006-2007$ & 10.00 \\
$1994-1995$ & 15.00 & $2007-2008$ & 0.00 \\
$1995-1996$ & 0.00 & $2008-2009$ & 20.00 \\
$1996-1997$ & 30.00 & $2009-2010$ & 1.50 \\
$1997-1998$ & 0.00 & $2010-2011$ & 0.00 \\
$1998-1999$ & 0.00 & $2011-2012$ & 0.00 \\
$1999-2000$ & 26.00 & $2012-2013$ & 0.00 \\
$2000-2001$ & 20.00 & & \\
\hline
\end{tabular}

In their natural regime, the $\mathrm{TD}$ are flooded as a result of the flat relief of this area (610-630 $\mathrm{m}$ a.s.1.) [18] and the high water table which surfaces in wet periods causing the natural discharge of the aquifer. The phreatic surface is currently found well below the topographic surface due to the influenced regime of the GWB (Figure 3), so that the process is inverted and this zone functions as an infiltration area, and therefore, as an aquifer recharge area. Nevertheless, according to the latest data in April 2013, the water table is about $3 \mathrm{~m}$ deep in the so called Ojos del Guadiana, the spring of the Guadiana River inside the Mancha Occidental I GWB (Figure 3).

In 1966 the Tablas de Daimiel were designated a national hunting reserve (Reserva Nacional de Caza); in 1979 they were designated as an ornithological special protection area (Zona de Especial Protección para las Aves ZEPA); The Tablas de Daimiel were designated a National Park (Parque Nacional de Las Tablas de Daimiel), in 1973, and reclassified in 1980. In 1982 it was included in the RAMSAR Convention and classified as a wetland of international importance [14] (Table 7).

What was formerly known as the Acuífero de la Mancha Occidental (Western Mancha Aquifer-WMA), which included the current GWBs Rus-Valdelobos, and Mancha Occidental I and II (Table 5), has been intensively exploited since the 1970s. In the last 40 years the intensive use of groundwater in the $5000 \mathrm{~km}^{2}$ area of the WMA has represented the extraction of around 20,000 million of $\mathrm{m}^{3}\left(\mathrm{Mm}^{3}\right)$ of water, with $3,000 \mathrm{Mm}^{3}$ coming from groundwater storage, causing a 
$25 \mathrm{~m}$ drawdown of the water level [19,20]. As a consequence, the Guadiana Water Authority (CHG in its Spanish acronym), agreed in 1987 to declare the WMA provisionally overexploited. Later, in 1994, it was declared definitively overexploited.

Figure 3. Evolution of piezometric level close to the Tablas de Daimiel [data provided by Miguel Mejías-Geological Survey of Spain (IGME)].

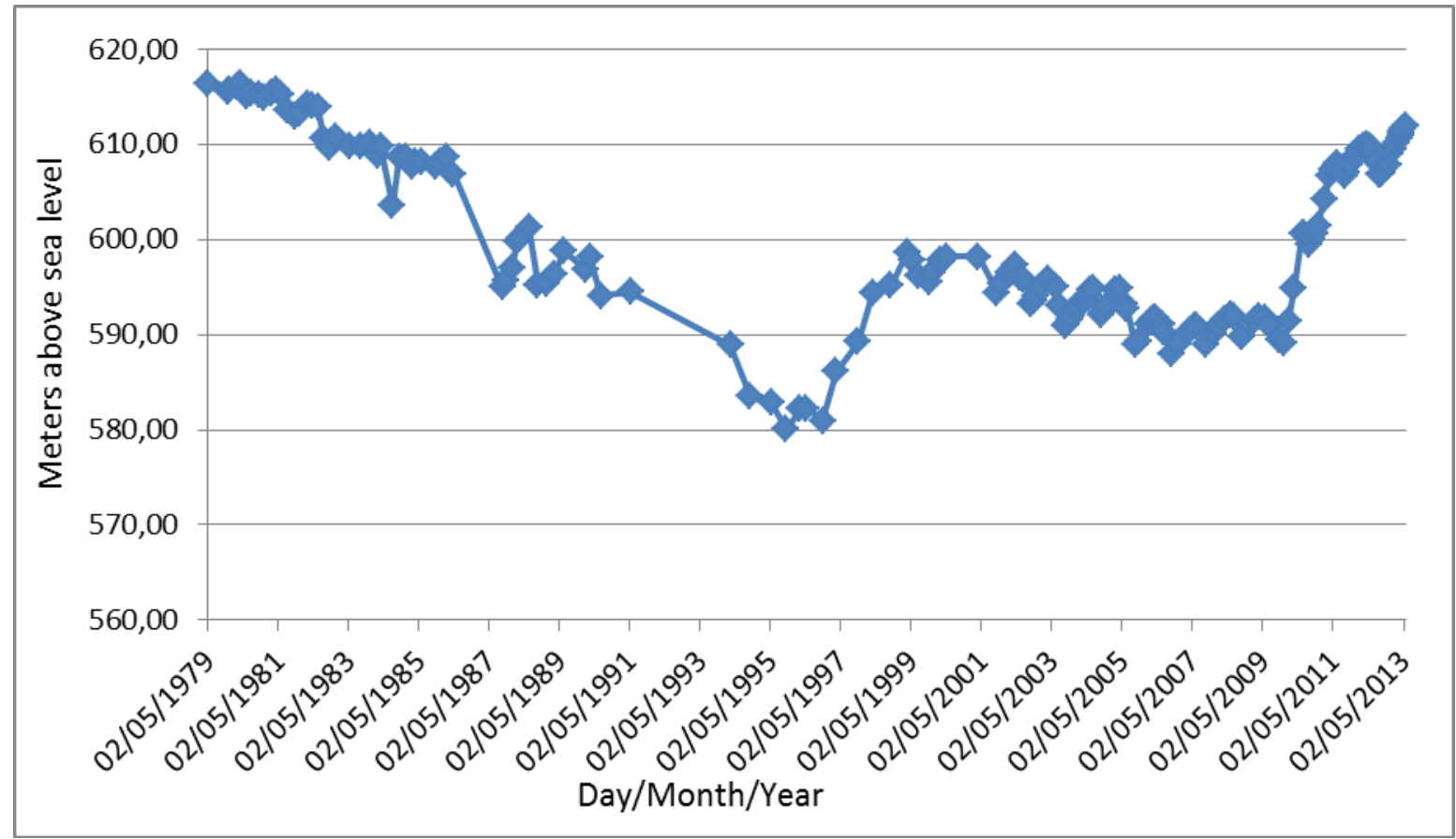

Table 7. Legally protected categories applying to the Tablas de Daimiel wetland.

\begin{tabular}{ll}
\hline Year & \multicolumn{1}{c}{ Protected category } \\
\hline 1966 & National Hunting Reserve \\
1973 & National Park \\
1979 & ZEPA \\
1980 & Reclassified \\
1980 & TD included in the Mancha Húmeda Biosphere Reserve \\
1982 & Included in Ramsar List \\
\hline
\end{tabular}

TD has a strong symbolic value for a number of reasons. It represented a landmark in a largely arid and poor region, which thanks to natural springs and so called tablas, provided sustenance for the local population from fisheries, crabbing and associated land uses like small orchards. It is also a reference in Spanish conservation history as a symbol for reversing existing policies. Some watercourses were channeled and modified to increase agricultural land at the beginning of the same year that the Park was designated (1973).

The TD wetlands system is sustained by the WMA aquifer (Figure 2 and Table 5). This is an unconfined aquifer composed of limestone in its upper part. Deeper down there are siltstones, sands and conglomerates, all from the Miocene age. The basement of the basin is composed of Jurassic and Cretaceous carbonate materials in the east and of impervious Palaeozoic and Triassic materials in the 
west. The hydrogeological cross section (Figure 4) shows that the lowered water table has left the TD suspended over the saturated zone of the aquifer, which at present is still the case [19].

Figure 4. Evolution of the water table in the Tablas de Daimiel area (adapted from [21]). The position of the hydrogeological cross section is shown in Figure 2.

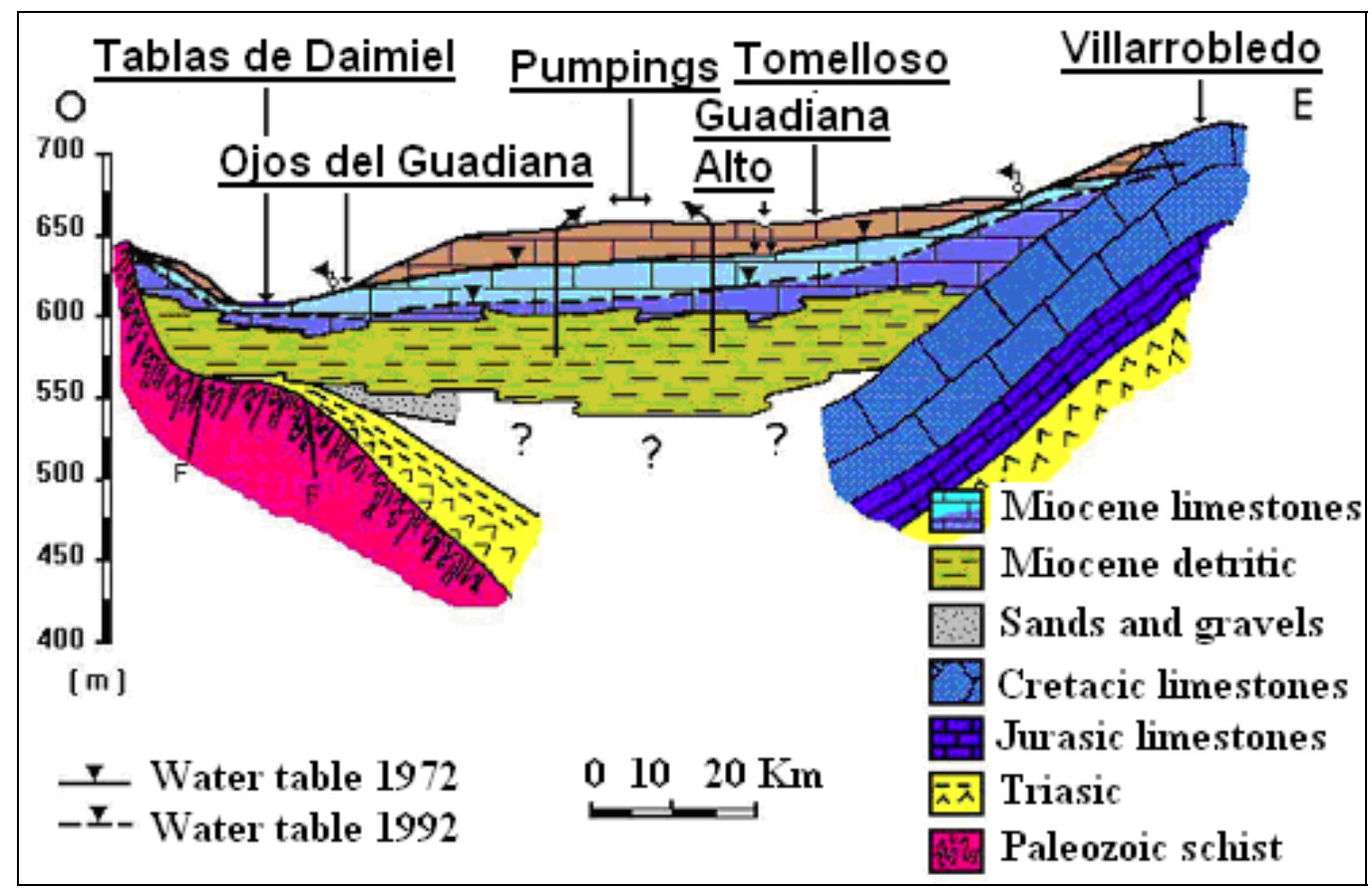

Over a relatively short period of time the area went through a profound socio-ecological transformation with large environmental externalities, since groundwater stopped overflowing from the WMA into TD. From 1974 to 1984 groundwater use grew from less than $200 \mathrm{Mm}^{3} /$ year to $500 \mathrm{Mm}^{3} /$ year, when the estimated renewable resources were from 260 to $300 \mathrm{Mm}^{3} /$ year. The record of extractions was reached in 1988 with the pumping of $570 \mathrm{Mm}^{3}$ [22]. The area under irrigation over the same period increased over four times, from 30,000 ha to 130,000 ha (Figure 5).

There have been a number of public policy measures that have been implemented in the area to address the conflict between agriculture and wetland protection. The most recent public policy initiative is the Special Plan for the Upper Guadiana (SPUG) approved in 2008. It is considered the most important part of the Action Plan for the future Guadiana Hydrological Plan, conceived to restore the three groundwater bodies that cover the WMA to comply with the WFD $[23,24]$.

Since January 2010 (Table 6) no water has been transferred to the TD and no other measures have been taken, as rainfall has been heavy. The TD have made a spectacular recovery and have reached their maximum recorded extent. Similarly, the aquifer levels have risen drastically (Figure 3) at some points [20], although without reaching the original levels of the early 1970s. 
Figure 5. Evolution of the piezometric level, agricultural groundwater abstraction and irrigated area between 1974 and 2008 [23].

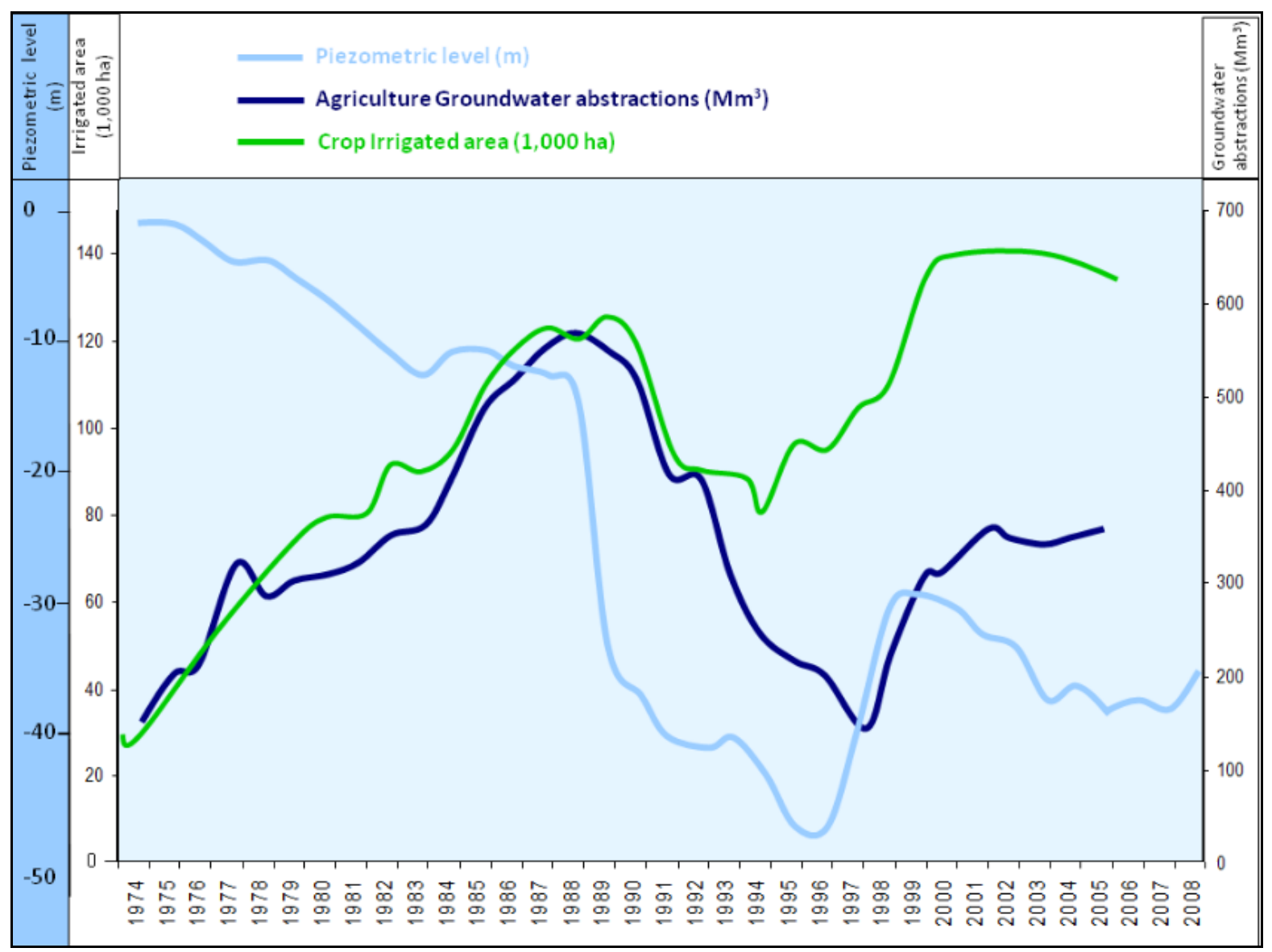

\subsection{Ruidera Lakes}

These unique wetlands are of significant value in the interior of the arid Castilla-La Mancha plateau. This area is renowned for its magnificent fauna and freshwater flora, rich biodiversity, beautiful landscape, the colour of its clear waters and the traditional folklore related to the subterranean rivers, mentioned in the adventures of Don Quixote. The lake water is basically groundwater, which resurges in springs and pools to form a chain of 15 lakes (Figure 6 and Table 8). These appear as a 35-kilometer-long series of steps with a difference in height of $120 \mathrm{~m}$ between the highest and lowest [25]. The lakes are connected by torrents, waterfalls, springs or channels which are dammed by a series of natural dikes resulting from carbonate precipitation (travertine) on small original barriers [26]. The series of lakes covers a surface area of 300 ha with a dammed volume of around $23 \mathrm{Mm}^{3}$. The Ruidera Lakes (RL) are located on a carbonated upland on the northern edge of the central peninsular plateau (Figure 2). The local geology is composed of a Palaeozoic metamorphic basement (quartzite and slate) with a heterogeneous deposit of Mesozoic sediments (Triassic and Jurassic). The Triassic-Jurassic complex varies considerably in depth and is affected by fractures, folds and diapiric processes. The end result is a compartmentalization of the aquifer materials, affecting its hydrological function. The upper Triassic layer is composed of marls and gypsum-rich clays, forming an impervious bedrock under the Jurassic carbonate materials of the Campo de Montiel aquifer. It is interesting to note the Quaternary travertine deposits, various metres 
thick, on which the series of lakes are located (Figure 6). Some of these are evidently older, and are several metres above the current level of the lakes.

Figure 6. Ruidera Lakes showing the cross section also represented in Figure 7 (adapted from [25] and [27]).

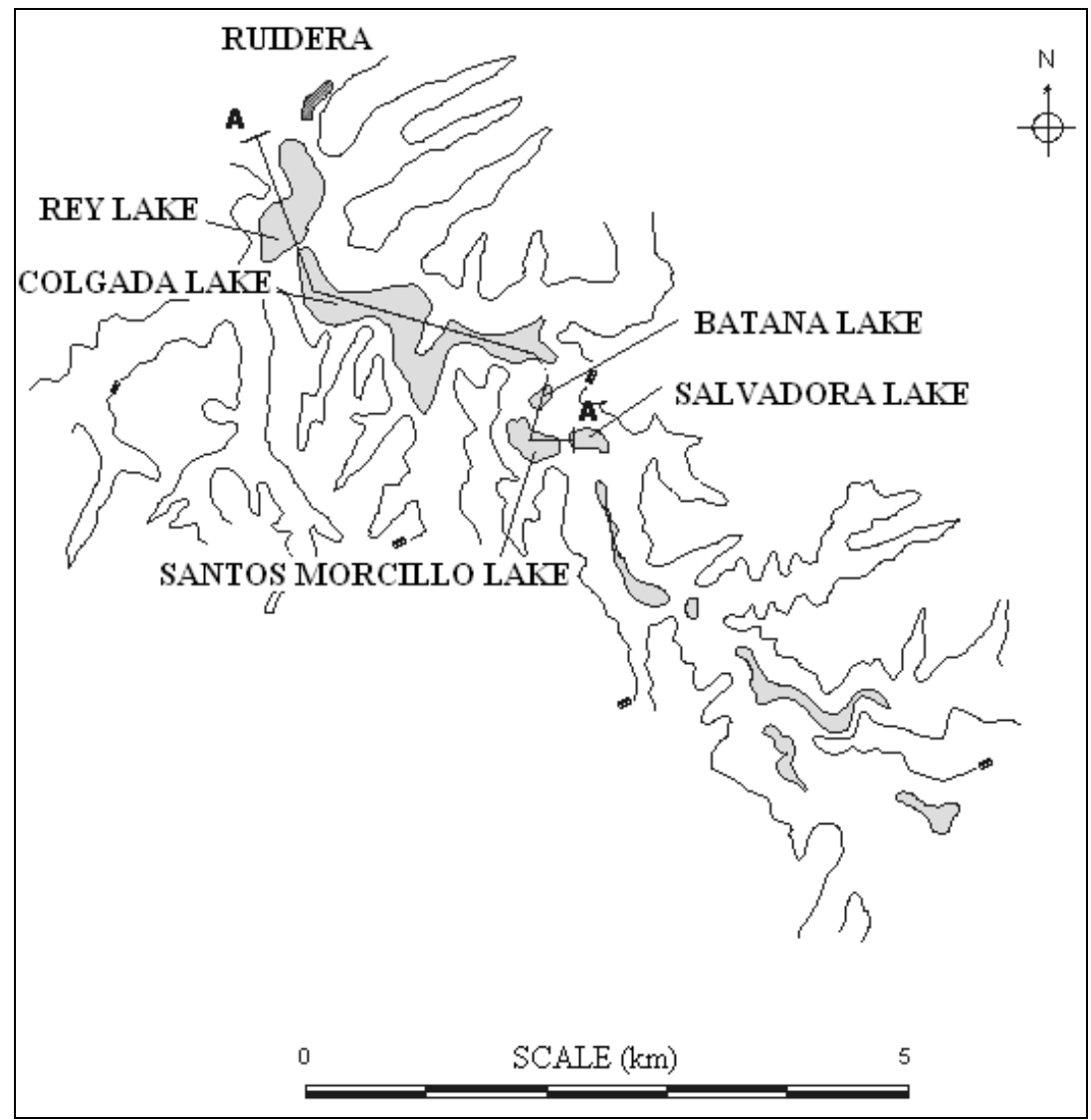

Table 8. Morphometric parameters of Ruidera Lakes (developed and adapted from [25] completed with results obtained through Google Earth).

\begin{tabular}{lccc}
\hline Lake & Length $(\mathbf{m})$ & Width $(\mathbf{m})$ & Depth $(\mathbf{m})$ \\
\hline Blanca $(980 \mathrm{~m}$ asl) & 850 & 400 & Minimal \\
Concejo & 1990 & $300-400$ & 14 \\
Tomilla & 500 & $300-400$ & 14 \\
Tinaja & 600 & 200 & 17 \\
S. Pedro & 1600 & 400 & 21 \\
Redondilla & 190 & 190 & 10 \\
Lengua & 1400 & 250 & 14 \\
Salvadora & 450 & 400 & 12 \\
Santos Morcillo & 800 & 400 & 14 \\
Batana & 400 & 400 & 8 \\
Colgada & 2400 & 400 & 18 \\
Del Rey & 950 & 400 & 20 \\
Cueva Morenilla & 600 & 180 & 7,85 \\
Coladilla & 400 & 300 & 7,55 \\
Cenagosa (720 msnm) & 400 & 250 & Minimal \\
\hline
\end{tabular}


The RL are located over the $2500 \mathrm{~km}^{2} 040.010$ Campo de Montiel groundwater body (Figure 2). Due to problems in the mid 1980s attributed to the pumping of irrigation wells, the relevant authorities declared the Campo de Montiel aquifer provisionally overexploited in 1988 and definitively overexploited in 1989, although the renewable resources are officially $125 \mathrm{Mm}^{3} /$ year and the abstractions only $35 \mathrm{Mm}^{3} /$ year. The rest is water transferred to the Mancha Occidental II GWB (between $20 \mathrm{Mm}^{3}$ and $50 \mathrm{Mm}^{3}$ ) and surface runoff water that drains to the RL [19].

The lakes have been protected to some extent for many years: in 1933 they were declared a Natural Site of National Interest. Since July 1979 the area has been a Natural Park and more recently, in 2011, was declared a Ramsar area of international importance.

Figure 7. Hydrogeological cross section of Ruidera Lakes (adapted from [25] and [27]).

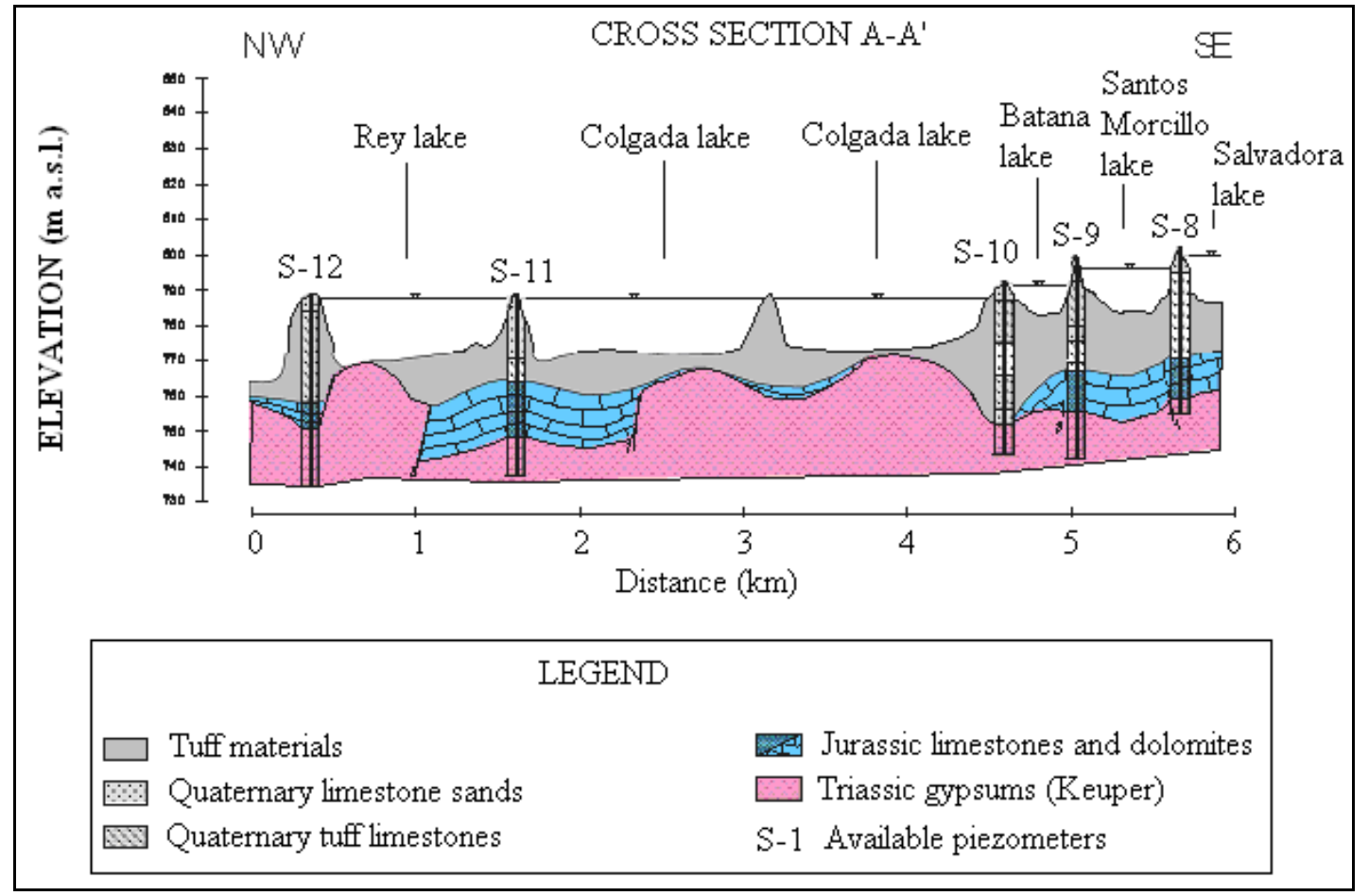

The water in the lakes is basically groundwater, which surfaces in springs and pools in the series of lakes described above. Montero [28] shows that the water level in the RL depends to a considerable extent on the geometry of the lake basin, on the geological structure and on the level of abstractions from the aquifer and its function. This means that some lakes are closely linked to the Jurassic aquifer, others are fed by surface water supplied by the channels connecting them to the lake immediately above, and a third group of lakes (i.e., La Colgada and Del Rey) are supplied from lateral surface water and from the lakes upstream.

Existing problems include contamination by nitrates used in agriculture, wastewater discharge (now almost eliminated as a result of the recently inaugurated Ruidera wastewater treatment plant), and the adverse effects of tourism within the whole perimeter of the RL, which may affect water quality. Other threats include access routes, periodic burning of stubble, felling timber for charcoal, or over-grazing.

The studies by Montero [25] and Eugercios [29] have highlighted how sensitive the lake water levels are to aquifer pumping. This aquifer has very little regulatory power due to its high permeability 
resulting from the karstification of the aquifer (which means it empties quickly) and also to the shallow saturated layer.

In recent years, successive episodes of intense rainfall have filled the lakes: in 1996-1997, from December 2009 until the summer of 2012, and again at present (spring 2013).

\section{Assessment of the Two Wetlands Case Studies}

In this section the methodology proposed by Bocanegra et al. [11] is slightly modified and applied to the two case studies: Tablas de Daimiel (TD) and the Ruidera Lakes (RL).

\subsection{Tablas de Daimiel}

In the case of this wetland, the economic development process in the surrounding area with groundwater pumping occurred at the same time as the growing social awareness of its environmental value [30].

Under natural conditions, the TD provided a whole series of services, which basically correspond, to two main types: regulation and culture (Table 1). Some water supply services, although less important, could also be mentioned.

- Regulation services include important water regulation, due to topographical conditions. This wetland is a very flat, wide plain that retains flood waters. According to Camargo et al. [31] and MAGRAMA records [32], the greatest extension was in 1956. Extensive flooded areas were also recorded in 1988, 2004, 2010, and at present (spring 2013), with minimum levels recorded in 1994. This wetland provides a positive hydric anomaly in a semi-arid zone, with mean annual precipitation of less than $450 \mathrm{~mm} /$ year.

- Cultural services provided include the landscape and its aesthetic value, as this is an area of special beauty for rest and recreation. The area also has its own significant cultural identity, recognised on a local, regional and national scale.

- Supply services include:

(a) Production of biological raw materials, such as reeds and willows, used in traditional basket-making and related crafts. Fisheries are also significant;

(b) Peat generation at a certain depth, within the saturated zone;

(c) Existence of medicinal herbs and plants.

In the past the TD also provided other services, which should be mentioned here but are not contemplated in the method proposed by Bocanegra et al. [11]:

(a) Carbon sink;

(b) Development of autochthonous flora and fauna. The native flora has undergone significant changes [31] and the fauna is allochthonous or in transit, but ever smaller numbers of birds are permanent residents of this wetland. Studies of the changes in vegetation patterns include [33] and [34];

(c) The wetland functions as a discharge area for the aquifer, supporting the aquatic ecosystem. 
At present, the services (Table 1) provided by this wetland are very different. Supply services provided include:

(a) Water supply for other uses. As the wetland currently operates as an aquifer recharge zone and receives artificial supplies from the Tajo-Segura aqueduct, which include freshwater of higher quality than the autochthonous groundwater from the WMA, the local farmers take advantage of the aquifer recharge for irrigation (for both irrigated and non-irrigated crops).

(b) Destruction of biological raw materials. The lower water table level in the WMA has left peat deposits in the saturated zone exposed to aerobic conditions. As these deposits were then within the non-saturated zone, the peat was subject to spontaneous combustion processes, as occurred in the 1980s [34,35], and more recently in 2009 [36] posing a severe threat to the physical structure of the ecosystem and the quality of the underlying groundwater.

(c) Human drivers of ecosystem change have affected the capacity of this wetland to store carbon and carbon flow, as shown in research on the sedimentary record, including geochemistry and pollen studies, together with historical data [37].

(d) Berzas et al. [38] recognise the appearance of a serious salinization process, which may affect wetland life conditions, and assess the current state of organic and inorganic contamination, including trace metals for the first time.

(e) Water purification has been one of the new functions of the wetland; from the point at which its hydrological function was inverted and it became an aquifer recharge area. According to Navarro et al. [39] there is a direct functional interdependence between the infiltration rate and the flooded area. Castaño et al. [40] assess the quantity of water needed to maintain system operativity, using the average loss from infiltration. On several occasions wastewater discharges from industrial estates and of urban wastewater have occurred upstream from the TD. The repeated discharges in April, May and June 1997 were particularly damaging [41].

(f) Return of irrigation water has contributed to both soil salinization and contamination of the ecosystem from organic material $[42,43]$, nitrogen and phosphorous from specific sources (urban centres and agrifood industry) and non-specific sources (agricultural practices within the basin) [44].

(g) The differences between the physico-chemical characteristics of the original water supplying the lakes and the current supply have caused important ecological changes to the ecosystem, analysed by [45].

In terms of cultural services, mention must be made of the increase and development of ecotourism (Table 9). The Tablas de Daimiel have also developed an important educational role, with the creation of the Centro del Agua de Daimiel Visitor Centre as a local and regional educational prototype.

With reference to regulation services, hydric regulation continues to be a currently active service in this wetland. However, the saturated soil conditions and peat fires have seriously altered the conditions of water permanence in this wetland $[36,46]$.

It can be seen, therefore, that there has been a radical change in the services formerly provided by the TD wetland and those currently provided. It remains to be discussed and analysed whether these service changes are due to social evolution or to a transformation forced by human change drivers, or to both these factors. The role of water availability seems to have affected the ecological connectivity. 
Table 9. Number of visitors to the TD National Park (Data provided by [32]).

\begin{tabular}{cccc}
\hline Year & Number of visitors & Year & Number of visitors \\
\hline 2005 & 123,413 & 2009 & 105,957 \\
2006 & 100,099 & 2010 & 398,742 \\
2007 & 122,955 & 2011 & 204,314 \\
2008 & 94,687 & & \\
\hline
\end{tabular}

It should be noted, however, that the number of visits falls sharply in dry years.

The services described are shown in Table 10, assigned according to the descriptors shown in Table 2. Table 10 also shows the trends for each service identified and the knowledge level in each case. For the high quality water supply it should be noted that the use of agricultural fertilizers in the surroundings of the TD contributes to the presence of nitrates in the irrigation return water, to the detriment of the surface water quality.

Table 10. Status evaluation $(\mathrm{S})$, trends $(\mathrm{T})$ and knowledge level $(\mathrm{K})$ of the Tablas de Daimiel wetland. Differentiating within status: natural conditions (NC), disturbed conditions (DC) and current conditions (CC): $\mathrm{H}=$ high; $\mathrm{M}=$ medium; $\mathrm{L}=$ low; $\mathrm{Ne}=$ non-existent; $\mathrm{U}=$ unknown. Within service trend $(\mathrm{T}): 1=$ improved; $2=$ improving; $3=$ stable; $4=$ deteriorating; 5 = deteriorated. Within knowledge level $(\mathrm{K})$ : A = acceptable; $\mathrm{L}=$ low; $\mathrm{N}=\mathrm{Nil}$.

\begin{tabular}{llccc}
\hline \multirow{2}{*}{ Service type } & Service & \multicolumn{1}{c}{$\mathbf{S}$} & $\mathbf{T}$ & K \\
& & NC/DC/CC & NC-DC/DC-CC & NC/DC/CC \\
\hline \multirow{5}{*}{ Supply } & High quality water supply & $\mathrm{Ne} / \mathrm{Ne} / \mathrm{H}$ & 4 & $\mathrm{~N} / \mathrm{L} / \mathrm{L}$ \\
& Water supply for other uses & $\mathrm{Ne} / \mathrm{Ne} / \mathrm{H}$ & & $\mathrm{N} / \mathrm{N} / \mathrm{N}$ \\
& Natural production of food resources & $\mathrm{L} / \mathrm{Ne} / \mathrm{Ne}$ & & $\mathrm{N} / \mathrm{N} / \mathrm{N}$ \\
& Artificial production of food resources & $\mathrm{Ne} / \mathrm{Ne} / \mathrm{Ne}$ & & $\mathrm{N} / \mathrm{N} / \mathrm{N}$ \\
& Production of biological raw materials & $\mathrm{H} / \mathrm{M} / \mathrm{L}$ & 2 & $\mathrm{~A} / \mathrm{L} / \mathrm{L}$ \\
& Production of mineral raw materials & $\mathrm{Ne} / \mathrm{Ne} / \mathrm{Ne}$ & 3 & $\mathrm{~N} / \mathrm{N} / \mathrm{N}$ \\
& Natural species of medicinal interest & $\mathrm{H} / \mathrm{L} / \mathrm{Ne}$ & 3 & $\mathrm{~N} / \mathrm{N} / \mathrm{N}$ \\
\hline \multirow{5}{*}{ Regulation } & $\mathrm{H} / \mathrm{H} / \mathrm{H}$ & 2 & $\mathrm{~A} / \mathrm{A} / \mathrm{A}$ \\
& Water regulation & $\mathrm{Ne} / \mathrm{H} / \mathrm{H}$ & 2 & $\mathrm{~N} / \mathrm{L} / \mathrm{A}$ \\
& Water purification & $\mathrm{H} / \mathrm{H} / \mathrm{H}$ & 2 & $\mathrm{~N} / \mathrm{L} / \mathrm{L}$ \\
& Erosion control & $\mathrm{H} / \mathrm{H} / \mathrm{H}$ & 2 & $\mathrm{~L} / \mathrm{L} / \mathrm{L}$ \\
\hline \multirow{5}{*}{ Culture } & Local climate regulation & $\mathrm{H} / \mathrm{H} / \mathrm{H}$ & 1 & $\mathrm{~L} / \mathrm{A} / \mathrm{A}$ \\
& Tourism & $\mathrm{H} / \mathrm{H} / \mathrm{H}$ & 1 & $\mathrm{~L} / \mathrm{A} / \mathrm{A}$ \\
& Education & $\mathrm{H} / \mathrm{H} / \mathrm{H}$ & 2 & $\mathrm{~A} / \mathrm{A} / \mathrm{A}$ \\
& Landscape and natural beauty & $\mathrm{H} / \mathrm{H} / \mathrm{H}$ & 1 & $\mathrm{~A} / \mathrm{A} / \mathrm{A}$ \\
& Cultural identity & $\mathrm{U} / \mathrm{U} / \mathrm{U}$ & 4 & $\mathrm{~N} / \mathrm{N} / \mathrm{N}$ \\
\hline
\end{tabular}

In view of the explanation in Section 3.1, Table 11 summarizes the factors driving direct changes in the Tablas de Daimiel wetland, assigned according to the descriptors shown in Tables 2 and 4. 
Table 11. Summary of factors driving direct change in services currently provided by the Tablas de Daimiel wetland.

\begin{tabular}{|c|c|c|c|c|}
\hline & Group & Factor & Impact & Forecast \\
\hline \multirow{7}{*}{$\begin{array}{l}\text { Intensive } \\
\text { exploitation } \\
\text { of resources }\end{array}$} & \multirow{3}{*}{ Water extraction } & From influent streams & $\mathrm{Ne}$ & $=$ \\
\hline & & Nearby groundwater & $\mathrm{H}$ & - \\
\hline & & Basin groundwater & $\mathrm{H}$ & - \\
\hline & \multirow{3}{*}{ Biological exploitation } & Crops & $\mathrm{Ne}$ & $=$ \\
\hline & & Fisheries & $\mathrm{Ne}$ & $=$ \\
\hline & & Other & $\mathrm{Ne}$ & $=$ \\
\hline & Mineral exploitation & Soils & $\mathrm{Ne}$ & $=$ \\
\hline \multirow{7}{*}{\multicolumn{2}{|c|}{ Changes in ground use }} & Deforestation & $\mathrm{L}$ & $=$ \\
\hline & & Reforestation & M & $=$ \\
\hline & & Species substitution & $\mathrm{L}$ & $=$ \\
\hline & & Extensive agriculture & M & $=$ \\
\hline & & Extensive livestock farming & $\mathrm{L}$ & $=$ \\
\hline & & Building & $\mathrm{Ne}$ & $=$ \\
\hline & & Communication routes & $\mathrm{L}$ & $=$ \\
\hline \multirow{3}{*}{\multicolumn{2}{|c|}{ Changes in the hydrological cycle }} & Drainage & M & $=$ \\
\hline & & Artificial replenishment & $\mathrm{H}$ & + \\
\hline & & Urban water contributions & $\mathrm{L}$ & - \\
\hline \multirow{2}{*}{\multicolumn{2}{|c|}{ Contamination }} & Widespread/agricultural & M & - \\
\hline & & Localized urban/industrial & $\mathrm{L}$ & - \\
\hline \multirow{4}{*}{\multicolumn{2}{|c|}{ Change-related effects }} & Water quality - mineral & $\mathrm{L}$ & - \\
\hline & & Water quality -biological & $\mathrm{L}$ & - \\
\hline & & Oxidation resulting from lower water table & M & $=$ \\
\hline & & Soil destruction & $\mathrm{M}$ & $=$ \\
\hline \multirow{2}{*}{\multicolumn{2}{|c|}{ Climate and global change }} & Precipitation & $\mathrm{H}$ & $=$ \\
\hline & & Temperature & $\mathrm{H}$ & $=$ \\
\hline
\end{tabular}

\subsection{Ruidera Lakes}

In contrast to the Tablas de Daimiel, this wetland has hardly seen any changes in the services that it provided in the past and currently continues to provide to humans. Basically the wetland continues to function as the discharge area for the aquifer, forms a hydric regulation zone and also performs a climatic regulation function. It can be seen that hunting as a sport has contributed to the improved economy of the area [24]. According to Eugercios [25], agricultural practices have significantly increased the nitrate content in the lakewater.

The services provided by this wetland in natural conditions are shown in Table 12 assigned according to the descriptors shown in Table 2 and Table 13 show the factors driving change in RL. 
Table 12. Status evaluation (S) differentiating between natural conditions (NC) and current conditions (CC), trends (T) and knowledge level (K) of the Ruidera Lakes wetland.

\begin{tabular}{clccc}
\hline \multirow{2}{*}{ Service type } & Service & $\begin{array}{c}\text { S } \\
\text { NC/CC }\end{array}$ & $\begin{array}{c}\text { T } \\
\text { (NC-CC) }\end{array}$ & K \\
\hline \multirow{5}{*}{ Supply } & High quality water supply & $\mathrm{L} / \mathrm{M}$ & 2 & $\mathrm{~A}$ \\
& Water supply for other uses & $\mathrm{L} / \mathrm{M}$ & 2 & $\mathrm{~A}$ \\
& Natural production of food resources & $\mathrm{L} / \mathrm{L}$ & 3 & $\mathrm{~A}$ \\
& Artificial production of food resources & $\mathrm{L} / \mathrm{L}$ & 3 & $\mathrm{~A}$ \\
& Production of biological raw materials & $\mathrm{H} / \mathrm{H}$ & 3 & $\mathrm{~A}$ \\
& Production of mineral raw materials & $\mathrm{L} / \mathrm{L}$ & 3 & $\mathrm{~A}$ \\
& Natural species of medicinal interest & $\mathrm{Ne} / \mathrm{Ne}$ & 3 & $\mathrm{~A}$ \\
\hline \multirow{5}{*}{ Regulation } & $\mathrm{L} / \mathrm{L}$ & 3 & $\mathrm{~A}$ \\
& Water regulation & $\mathrm{Ne} / \mathrm{Ne}$ & 3 & $\mathrm{~A}$ \\
& Water purification & $\mathrm{L} / \mathrm{L}$ & 3 & $\mathrm{~L}$ \\
& Erosion control & $\mathrm{H}$ & 3 & $\mathrm{~L}$ \\
\hline & Local climate regulation & $\mathrm{M} / \mathrm{H}$ & 2 & $\mathrm{~A}$ \\
& Tourism & $\mathrm{M} / \mathrm{H}$ & 2 & $\mathrm{~A}$ \\
& Education & $\mathrm{H} / \mathrm{H}$ & 1 & $\mathrm{~A}$ \\
& Landscape and natural beauty & $\mathrm{H} / \mathrm{H}$ & 1 & $\mathrm{~A}$ \\
& Cultural identity & $\mathrm{Ne} / \mathrm{Ne}$ & 2 & $\mathrm{~A}$ \\
\hline
\end{tabular}

Table 13. Summary of factors driving change in the Ruidera Lakes wetland.

\begin{tabular}{|c|c|c|c|c|}
\hline & oup & Factor & Impact & Forecast \\
\hline \multirow{7}{*}{$\begin{array}{l}\text { Intensive } \\
\text { exploitation } \\
\text { of resources }\end{array}$} & \multirow{3}{*}{$\begin{array}{l}\text { Water } \\
\text { extraction }\end{array}$} & From influent streams & $\mathrm{Ne}$ & $=$ \\
\hline & & Nearby groundwater & $\mathrm{M}$ & $=$ \\
\hline & & Basin groundwater & $\mathrm{L}$ & $=$ \\
\hline & \multirow{3}{*}{$\begin{array}{l}\text { Biological } \\
\text { exploitation }\end{array}$} & Crops & $\mathrm{Ne}$ & $=$ \\
\hline & & Fisheries & $\mathrm{L}$ & $=$ \\
\hline & & Others & $\mathrm{Ne}$ & $=$ \\
\hline & $\begin{array}{l}\text { Mineral } \\
\text { exploitation }\end{array}$ & Soils & $\mathrm{Ne}$ & $=$ \\
\hline \multirow{7}{*}{\multicolumn{2}{|c|}{ Changes in ground use }} & Deforestation & $\mathrm{L}$ & $=$ \\
\hline & & Reforestation & M & $=$ \\
\hline & & Species substitution & $\mathrm{Ne}$ & $=$ \\
\hline & & Extensive agriculture & $\mathrm{L}$ & $=$ \\
\hline & & Extensive livestock farming & $\mathrm{L}$ & $=$ \\
\hline & & Building & $\mathrm{M}$ & $=$ \\
\hline & & Communication routes & $\mathrm{M}$ & $=$ \\
\hline \multirow{3}{*}{\multicolumn{2}{|c|}{$\begin{array}{l}\text { Changes in the hydrological } \\
\text { cycle }\end{array}$}} & Drainage & $\mathrm{Ne}$ & $=$ \\
\hline & & Artificial recharge & $\mathrm{Ne}$ & $=$ \\
\hline & & Urban water contributions & $\mathrm{L}$ & $=$ \\
\hline \multirow{2}{*}{\multicolumn{2}{|c|}{ Contamination }} & Widespread/agricultural & $\mathrm{H}$ & - \\
\hline & & Localized urban/industrial & $\mathrm{M}$ & - \\
\hline
\end{tabular}


Table 13. Cont.

\begin{tabular}{clcc}
\hline \multicolumn{1}{c}{ Group } & Factor & Impact & Forecast \\
\hline & Water quality-mineral & $\mathrm{Ne}$ & $=$ \\
\multirow{4}{*}{ Change-related effects } & Water quality-biological & $\mathrm{Ne}$ & $=$ \\
& Oxidation resulting from lower water table & $\mathrm{Ne}$ & $=$ \\
& Soil destruction & $\mathrm{Ne}$ & $=$ \\
\hline \multirow{2}{*}{ Climate and global change } & Precipitation & $\mathrm{H}$ & - \\
& Temperature & $\mathrm{H}$ & - \\
\hline
\end{tabular}

However, the value in cultural and recreational terms of Ruidera Lakes (RL) is increasing: 405,000 visitors in 2007 compared with 460,000 in 2011 [32].

\section{Discussion}

The methodology proposed by Bocanegra et al. [11] for assessing wetland status and evolution trends in the services provided has proved to be valid but needs to be modified to adapt it to the special conditions of the two wetlands analysed here.

The TD and RL present some similarities and some very different factors, which affect how the state of these wetlands evolves. Similarities include high levels of protection in both areas, which, because of measures adopted by the Water Authority, have been maintained up to the present day. Since 1973 the TD have been one of the fourteen designated National Parks in Spain, and the RL have been protected since 1933, forty years earlier. Both wetlands are very closely linked to climatic conditions and enter into cyclical 'crisis' periods during recurrent drought episodes. However, the differences between these wetlands are even more obvious. These are physical differences, as they are sustained by aquifers with very different geological and hydrological characteristics. The TD are sustained by various groundwater bodies with greater reserves than the RL, which has a low regulation capacity, making it more vulnerable to drought. An important characteristic to consider is the location of both wetlands within the Upper Guadiana basin: the RL are located far upstream so that the area affecting the water levels is exclusively within the basin headwater zone, in a relatively limited space with a single associated groundwater body. The TD, in contrast, are found in the lower part of the basin and are the result of a hydric balance of surface and groundwater of a very extensive basin, and are located downstream of eight groundwater bodies (Figure 2 and Table 5). The management criteria for each of these wetlands are therefore different.

Some of the services the wetlands used to provide have now disappeared, such as fisheries in the $\mathrm{TD}$, the gathering of willow and reeds for traditional basket-making crafts or the collection of medicinal plants. This trend seems to agree with Shuang et al. [7] who affirm that ecosystem services are becoming increasingly scarce.

Considerable changes have occurred in the hydrological function of the system. For example, the TD have changed from aquifer discharge lakes to an enormous complex that recharge the aquifer when flooded. Another notable variation in the hydrological cycle is the water accumulated upstream from the Puente Navarro dam (built to retain the water in the TD basin) and the drastic reduction of evapotranspiration (ETR) in the water balance in the aquifer, since as the water table is very deep the ETR has fallen from estimated values of $125 \mathrm{Mm}^{3}$ in natural conditions to zero at the present time [47,20]. 
To sum up, the conditions in both wetland areas can be considered as the result of the strict measures taken by the authorities that declared both aquifers to be overexploited and began limiting water extraction. The situation and function (above all in the case of the TD) are completely different from the natural conditions existing decades ago, although it could also be claimed that the status of both wetlands is stable. Within this equilibrium, maintained thanks to the steps taken, there is an observable maintenance trend with evident recovery of water levels in rainy periods and a worrying lowering of these levels in drought periods. It should be added here that the services that have now disappeared in the case of the Tablas de Daimiel seem to be non-recoverable as long as current groundwater management conditions are maintained.

\section{Concluding Remarks}

The method proposed by Bocanegra et al. [11] is appropriate and undoubtedly useful for Latin America and the Iberian Peninsula, for which it was originally designed. However, we consider that wide-ranging modifications would be needed to take into account the peculiarities of the Mediterranean climate: inter-annual prolonged periods of drought and intra-annual variations (a particularly dry summer). In this case, the methodology applied [11] is based on a snapshot used to evaluate functions and processes and the resulting services currently provided by the wetland without taking the past into account. This past comprises the processes, functions and services provided by the wetland in other conditions.

In our analysis we have used the above methodology to compare two specific moments of the two wetlands used in the case study: natural or non-disturbed conditions vs. current conditions. It shows that, on the one hand, the services provided by both wetlands have changed. This is not necessarily because the wetlands have stopped providing the service (e.g., basket-making or fishing in the case of the TD; or the use of water for hydroelectricity in the RL) but because the uses have been modified; i.e., at present there is no longer any social demand for these services. This highlights the fact that a wetland no longer provides a specific service when there is no further use for this service. This does not necessarily imply that the wetland has deteriorated, but rather that the change responds to how the social demand has evolved. These changes are not appropriately reflected in the methodology applied, which also requires a detailed analysis of each wetland. In parallel, it can also be seen that the social perception of the services provided by the wetlands has changed. What used to be considered useful is no longer considered as such.

From the results of the analysis of the two wetlands we detect a gap in the time dimension of the methodology. A factor should be included to record the temporal variability (annual and inter-annual) of the wetlands, as this affects both the quality and the quantity of the water in the floodable zone. This factor directly affects the local ecological conditions and on a larger scale, the territorial connectivity conditions.

\section{Acknowledgments}

This study was carried out as part of the contribution of one of the authors to the UNESCO IGCP 604 project. We would like to thank Prof. Emilio Custodio and his team for allowing this paper to be presented. The authors work at two different Institutions. Notwithstanding, this paper is a personal 
initiative of the authors and thus the data cited and opinions expressed herein are theirs alone. The authors are also grateful to two anonymous reviewers for their comments and valuable suggestions. We appreciate the translation into English made by the Gabinete Lingüístico of the Universidad Complutense de Madrid (Pauline Moran and Bill Newton).

\section{References}

1. De la Hera, A.; Fornés, J.M.; Bernués, M. Ecosystem services of inland wetlands from the perspective of the EU Water Framework Directive implementation in Spain. Hydrol. Sci. J. 2011, $56,1656-1666$.

2. Carpenter, S.R.; DeFries, R.; Dietz, T.; Mooney, H.A.; Polasky, S.; Reid, W.V.; Scholes, R.J. Millennium ecosystem assessment: Research needs. Science 2006, 314, 257-258.

3. Homepage of Eureka Project. Available online: http://eureca.ew.eea.europa.eu (accessed on 4 June 2013).

4. UK Ecosystem Evaluation Homepage. Available online: http://uknea.unep-wcmc.org (accessed on 4 June 2013).

5. Economics of Ecosystems and Biodiversity Project Homepage. Available online: http://www.teebweb.org (accessed on 4 June 2013).

6. Montes, C.; Lomas, P. La Evaluación de los Ecosistemas del Milenio en España [The evaluation of the Millenium Ecosystem]. Ambienta. 2012. Available online: http://www.revistaambienta.es/ WebAmbiente/marm/Dinamicas/secciones/articulos/Montes.htm (accessed on 30 January 2013).

7. Shuang, L.; Costanza, R.; Farber, S.; Troy, A. Valuing ecosystem services: Theory, practice, and the need for a transdisciplinary synthesis. Ann. NY Acad. Sci. 2010, 1185, 54-78.

8. Pearce, D.W.; Turner, K.R. Economics of Natural Resources and the Environment; Harverster Wheatsheaf: London, UK, 1990.

9. Pearce, D.W.; Warford, J.W. World without End: Economics, Environment, and Sustainable Development; Oxford University Press: Oxford, UK, 1993.

10. Millennium Ecosystem Assessment, MA Ecosystems and human well-being: Synthesis; Island Press: Washington, DC, USA, 2005. Available online: http://www.millenniumassessment.org/ documents/document.356.aspx.pdf (accessed on 16 January 2013).

11. Bocanegra, E.; Manzano, M.; Betancur, T.; Custodio, E.; Cardoso, G. Caracterización preliminar de las interacciones aguas subterráneas-humedales-ser humano en Iberoamérica y en la Península Ibérica [Preliminary characterization of the interactions groundwater-wetlands-human being in Latin America and the Iberian Peninsula]. XI Congreso Latinoamericano de Hidrogeología y IV Congreso Colombiano de Hidrogeología [XI Latinoamerican Conference on Hydrogeology and IV Colombian Conference on Hydrogeology], Cartagena de Indias, Colombia, 20-24 August 2012; IAH-ALHSUD.

12. Millennium Ecosystem Assessment, MA. Ecosystems and Human Well-being. A Framework for Assessment; Island Press: Washington, DC, USA, 2003.

13. IGCP604 Project Homepage. Available online: http://www.mdp.edu.ar/hidrogeologia/IGCP604/ index.php (accessed on 4 June 2013). 
14. De la Hera, A. Análisis hidrológico de los humedales de la "Mancha Húmeda" y propuesta de restauración de un humedal ribereño: El Vadancho (Toledo) [Hydrological analysis of the wetlands of the "Mancha Húmeda" and restoration proposal of a riverain wetland: The Vadancho (Toledo)]. Ph.D. Dissertation, Department of Geodynamics, Faculty of Geology, Universidad Complutense, Madrid, Spain, 1999.

15. De la Hera, A. Conflictos Entre el Desarrollo de las Aguas Subterráneas y la Conservación de los Humedales [Conflicts between the Development of the Underground Waters and the Conservation of the Wetlands]; Coleto, C., Martínez-Cortina, L., Llamas, M.R., Eds.; Fundación Marcelino Botín, Ediciones Mundiprensa: Madrid, Spain, 2003; pp. 165-196.

16. Aguilera, H.; Castaño, S.; Moreno, L.; Jiménez-Hernández, M.E.; de la Losa, A. Model of hydrological behaviour of the antropized semiarid wetland of Las Tablas de Daimiel National Park (Spain) bades on surface wáter-groundwater interactions. Hydrogeol. J. 2013, 21, 623-641.

17. CHT Tagus Water Authority. Available online: http://www.chtajo.es/Paginas/default.aspx (accessed on 10 February 2013).

18. Dirección General del Medio Natural (DGMN). Ficha informativa de los humedales Ramsar [Informative card of the wetlands Ramsar]. Tablas de Daimiel. February 2006. Available online: http://www.magrama.gob.es/en/biodiversidad/temas/ecosistemas-y-conectividad/2_fir_tablas_ daimiel_01_tcm11-20663.pdf (accessed on 13 March 2013).

19. Mejías, M.; de la Losa, A.; Jiménez, E. Informe Sobre Evolución Piezométrica de la Unidad Hidrogeológica 04.04 (Mancha Occidental) [Reports on Piezometreical Evolution of the Unit Hidrogeológica 04.04 (Western Mancha)]; Instituto Geológico y Minero de España, IGME Documentation Centre, Madrid, Spain, 2009; Unpublished material.

20. Mejías Moreno, M.; López Gutiérrez, J.; Martínez Cortina, L. Características hidrogeológicas y evolución piezométrica de la Mancha Occidental. Influencia del periodo húmedo 2009-2011 [Hydrogeological characteristics and piezometrical evolution of the Western Mancha. Influence of the humid period 2009-2011]. Boletín Geol. Minero 2012, 123, 91-108.

21. García Rodríguez, M.; Llamas Madurga, M.R. Características geológicas del borde suroccidental de la Unidad Hidrogeológica 04.04 y su influencia sobre la hidrogeología de las Tablas de Daimiel [Geological characteristics of the southwestern edge of the Hydrogeological Unit 04.04 and his influence on the hydrogeology of the Tablas de Daimiel]. Geogaceta 1996, 20, 1271-1273.

22. Llamas, M.R.; Martínez-Santos, P.; de Stefano, L.; de la Hera, A.; Martínez-Cortina, L. Hydrological Aspects of Water Management and Climate Change in the Upper Guadiana Basin, Spain; Internal NeWater Report; 2007; Unpublished material.

23. Lopez Gunn, E.; Dumont, A.; Villarroya, F. Tablas de Daimiel National Park and Groundwater Conflicts. In Water, Agriculture and the Environment in Spain: Can We Square the Circle? de Stefano, L., Llamas, R., Eds.; CRC Press: London, UK, 2012; pp. 259-269.

24. Barcos, L.; Lopez-Gunn, E.; Villarroya, F.; Fernández-Lop, A.; Llamas, M.R. The Special Upper Guadiana Plan: Assessment of early effectiveness as main policy measure to implement the EU water framework directive. In Proceedings of the European Groundwater Conference, Madrid, Spain, 20-21 May 2010. 
25. Montero, E. Funcionamiento Hidrogeológico del Sistema de las LAGUNAS de Ruidera [Hydrogeological Functioning of the RUIDERA Lakes System]. Ph.D. Dissertation, Sciences Universidad Complutense de Madrid, Madrid, Spain, 1994; Volumes I and II.

26. BOE Real Decreto 13/2008, de 11 de enero, por el que se aprueba el Plan Especial del Alto Guadiana [Royal Decree by Which There Is Approved the Special Plan of the Upper Guadiana]; Boletín Oficial del Estado [Official State Bulletin]: Madrid, Spain, 2008; pp. 4608-4612.

27. Martínez-Santos, P.; Villarroya, F. Informe sobre la posible afección del colector de aguas residuales a las estructuras travertínicas del Parque Natural de las Ruidera Lakes. [Report on the possible affection of the collector of waste water to the tuff structures of the Nature Reserve of the Ruidera Lakes]. Interim Report for ISTMO 94, Sevilla, Spain, 2007.

28. Montero, E. Contribución al estudio de la geometría y los límites del acuífero del Campo de Montiel [Contribution to the Geometry and Boundering Limits of the Campo De Montiel Aquifer]; Instituto de Estudios Albacetenses Don Juan Manuel, Excma, Diputación de Albacete: Albacete, Spain, 2000.

29. Eugercios, A.R. Interacciones Acuífero-Lago y Biogeoquímica del Nitrógeno en Ambientes Kársticos [Interactions between Aquifer-Lake and Biogeochemical of Nitrogen in Karstic Environments]. Ph.D. Dissertation, Complutense University of Madrid, Madrid, Spain, 2013.

30. Martínez-Santos, P.; de Stefano, L.; Llamas, M.R.; Martínez-Alfaro, P.E. Wetland restoration in the Mancha Occidental aquifer, Spain: A critical perspective on water, agricultural, and environmental policies. Restor. Ecol. 2008, 16, 511-521.

31. Camargo, J.A.; Cirujano, S. Reduction in diversity of aquatic plants in a Spanish wetland: The effect of the size of inundated area. J. Freshw. Ecol. 1997, 12, 539-543.

32. MAGRAMA Ministry of Agriculture, Food and Environment. Available online: http:://www.magrama.es (accessed on 21 March 2013).

33. Álvarez-Cobelas, M.; Sánchez-Carrillo, S.; Cirujano, S.; Angeler, D.G. Long-term changes in spatial patterns of emergent vegetation in a Mediterranean floodplain: Natural versus anthropogenic constraints. Plant Ecol. 2008, 194, 257-271.

34. Álvarez-Cobelas, M.; Cirujano, S. Multilevel responses of emergent vegetation to environmental factors in a semiarid floodplain. Aquat. Bot. 2007, 87, 49-60.

35. García Rodríguez, M.; Llamas, M.R. Cambios paisajísticos en el alto Guadiana provocados por una extracción intensiva de agua subterránea [Landscape changes in the Upper Guadiana provoked by an intensive extraction of underground water]. Edit Asociación para el estudio del Paisaje: Madrid, Spain, 1993; pp. 91-102.

36. Moreno, L.; Jiménez, M.E.; Aguilera, H.; Jiménez, P.; de la Losa, A. The 2009 smouldering peat fire in las tablas de daimiel national park (Spain). Fire Technol. 2011, 47, 519-538.

37. Domínguez-Castro, F.; Santiesteban, J.I.; Mediavilla, R.; Dean, W.E.; López-Pamo, E.; Gil-García, M.J.; Ruíz-Zapata, M.B. Environmental and geochemical record of human-induced changes in $\mathrm{C}$ storage during the last millennium in a temperate wetland (Las Tablas de Daimiel National Park, Spain). Tellus Ser. B 2006, 58, 573-585.

38. Berzas, J.J.; García, L.F.; Rodríguez, R.C.; Martín-Álvarez, P.J. Evolution of the water quality of a managed natural wetland: Tablas de daimiel national park (Spain). Water Res. 2000, 34, 3161-3170. 
39. Navarro, V.; García, B.; Asensio, L. Characterization of the infiltration rate in las tablas de daimiel national park, central Spain. Hydrol. Processes 2012, 26, 367-378.

40. Castaño-Castaño, S.; Martínez-Santos, P.; Martínez-Alfaro, P.E. Evaluating infiltration losses in a Mediterranean wetland: Las Tablas de Daimiel National Park, Spain. Hydrol. Processes 2008, 22, 5048-5053.

41. Cirujano, S.; Álvarez, M. Estudio Limnológico y Botánico del Parque Nacional de las Tablas de Daimiel [Limnological and Botanical Study of the Tablas de Daimiel National Park]. Organismo autónomo Parques Nacionales-Consejo Superior de Investigaciones Científicas. Interim Report, Madrid, Spain, 1998.

42. Rodriguez-Murillo, J.C.; Almendros, G.; Knicker, H. Wetland soil organic matter composition in a Mediterranean semiarid wetland (Las Tablas de Daimiel, Central Spain): Insight into different carbon sequestration pathways. Org. Geochem. 2011, 42, 762-773.

43. Filella, M.; Rodríguez-Murillo, J.C.; Quentel, F. Natural organic matter quantification in the Waters of a semiarid freshwater wetland (Tablas de Daimiel, Spain). J. Environ. Sci. China 2013, 25, 114-123.

44. Álvarez-Cobelas, M.; Cirujano, S.; Sánchez-Carrillo, S. Hydrological and botanical man-made changes in the Spanish wetland of Las Tablas de Daimiel. Biol. Conserv. 2001, 97, 89-98.

45. Cirujano, S.; Casado, C.; Bernués, M.; Camargo, J.A. Ecological study of Las Tablas de Daimiel National Park (Ciudad Real, Central Spain): Differences in water physico-chemistry and vegetation between 1974 and 1989. Biol. Conserv. 1996, 75, 211-215.

46. Aguilera, H.; Moreno, L.; Jiménez-Hernández, M.E.; Castaño, S.; de la Losa, A. Management implications inferred from the multivariate análisis of vadose zone Chemicals variables in Las Tablas de Daimiel National Park (Spain). Geoderma 2011, 162, 365-377.

47. Martínez Cortina, L.; Mejías, M.; Díaz-Muñoz, J.A.; Morales-García, R.; Ruiz-Hernández, J.M. Cuantificación de recursos hídricos subterráneos en la cuenca alta del Guadiana. Consideraciones respecto a las definiciones de recursos renovables y disponibles [Quantification of water underground resources in the high basin of the Guadiana. Considerations with regard to the definitions of renewable and available resources]. Boletín Geol. Minero 2011, 122, 17-36.

(C) 2013 by the authors; licensee MDPI, Basel, Switzerland. This article is an open access article distributed under the terms and conditions of the Creative Commons Attribution license (http://creativecommons.org/licenses/by/3.0/). 